\title{
Title:
}

\section{Endoscopic closure of a duodenal perforation secondary to a migrated biliary plastic stent using hemoclips}

\section{Authors:}

Erol Cakmak

DOI: $10.17235 /$ reed.2022.8514/2021

Link: PubMed (Epub ahead of print)

Please cite this article as:

Cakmak Erol. Endoscopic closure of a duodenal perforation secondary to a migrated biliary plastic stent using hemoclips. Rev Esp Enferm Dig 2022. doi: 10.17235/reed.2022.8514/2021.

This is a PDF file of an unedited manuscript that has been accepted for publication. As a service to our customers we are providing this early version of the manuscript. The manuscript will undergo copyediting, typesetting, and review of the resulting proof before it is published in its final form. Please note that during the production process errors may be discovered which could affect the content, and all legal disclaimers that apply to the journal pertain. 


\section{Carta 8514 inglés}

Endoscopic closure of a duodenal perforation secondary to a migrated biliary plastic stent using hemoclips

\section{Erol Cakmak}

Department of Gastroenterology. Cumhuriyet University. Faculty of Medicine. Sivas, Turkey

Keywords: ERCP. Stent. Perforation.

Corresponding author:

Erol Cakmak

E mail: drecakmak@hotmail.com

Conflict of interest: the author declares no conflict of interest.

Dear Editor,

A 28-year-old female patient was admitted to our hospital with right upper quadrant pain and fever. The patient was diagnosed with acute cholangitis and choledocholithiasis. Stone removal was performed with Endoscopic retrograde cholangiopancreatography (ERCP) as it measured $1 \mathrm{~cm}$ in size and a $10-\mathrm{Fr} 10 \mathrm{~cm}$ straight plastic stent (Flexima ${ }^{\mathrm{TM}}$, Boston Scientific) was placed in the common bile duct. The patient was discharged after his symptoms subsided and was admitted to our hospital again two months later with abdominal pain, back pain, nausea and vomiting. On physical examination, mild tenderness was detected in the right upper quadrant. Laboratory tests showed a white blood cell (WBC) count of $6.82 \times 10^{9} / \mathrm{L}$, hemoglobin $10.3 \mathrm{~g} / \mathrm{mL}$, alanine aminotransferase (ALT) $19 \mathrm{U} / \mathrm{L}$, aspartate aminotransferase (AST) $18 \mathrm{U} / \mathrm{L}$ and total bilirubin (TB) $0.76 \mathrm{~g} / \mathrm{mL}$. All other laboratory parameters were normal. 
Abdominal computed tomography (CT) showed that the distal end of the plastic stent migrated to the lower wall of the third part of the duodenum and protruded into the peritoneal cavity. However, there was no evidence of perforation (Fig. 1A). During ERCP, it was observed that the proximal end of the plastic stent was in the bile duct and the distal end perforated the duodenal wall opposite the papilla (Fig. 1B). The plastic stent was held with rat-tooth forceps and removed with a slight upward movement towards the common bile duct and then a downward movement towards the lumen (Fig. 1C). Closure of the defect in the duodenum was performed with three hemostatic clips (Fig. 1D). Oral intake started a few days after the procedure and there were no complications. Duodenal perforation caused by migration of biliary stents is a rare complication. Abdominal CT scanning is usually preferred in these cases, and endoscopic intervention is an effective method for treatment.

\section{REFERENCES}

1. Gromski MA, Bick BL, Vega D, et al. A rare complication of ERCP: duodenal perforation due to biliary stent migration. Endosc Int Open 2020;8:1530-6. DOI: 10.1055/a-1231-4758

2. Bureau MA, Gkolfakis $P$, Blero $D$, et al. Lateral duodenal wall perforation due to plastic biliary stent migration: a case series of endoscopic closure. Endosc Int Open 2020;8:573-7. DOI: 10.1055/a-1123-7782

3. Wang X, Qu J, Li K. Duodenal perforations secondary to a migrated biliary plastic stent successfully treated by endoscope: case-report and review of the literature. BMC Gastroenterol 2020;12:149. DOI: 10.1186/s12876-020-01294-z

4. Esparza IR, Casero IA, Barroso AB. Endoscopic management of a duodenal perforation secondary to a migrated biliary plastic stent. Rev Esp Enferm Dig 2021;113:382. DOI: 10.17235/reed.2020.7271/2020 


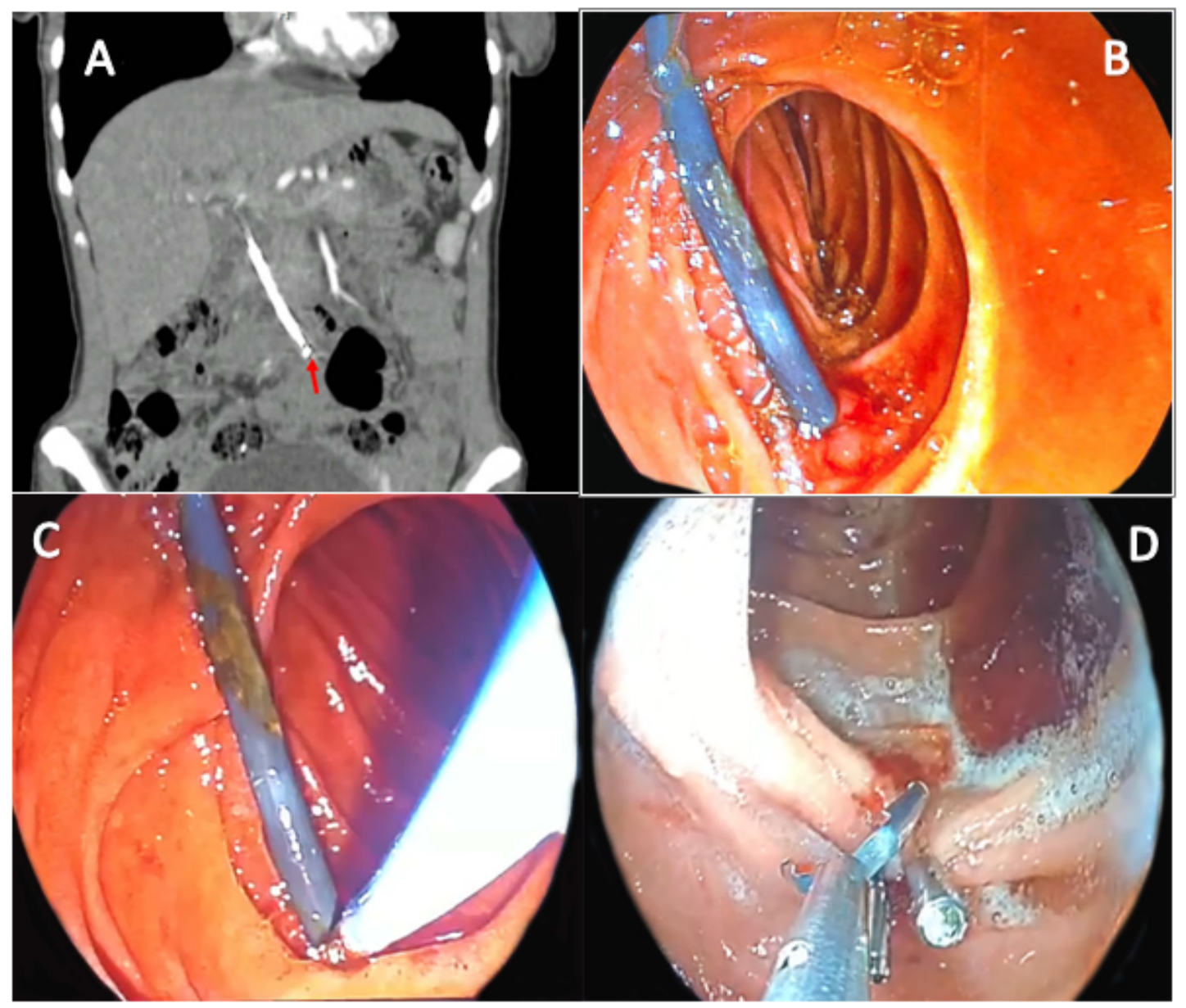

Fig. 1. A. Coronal view of an abdominal CT scan showing perforation and migration of the biliary plastic stent to the wall of the third part of the duodenum. B. Endoscopic view of a perforation of the distal end of the biliary plastic stent to the duodenal wall. C. The migrated plastic stent was extracted by rat-tooth forceps. D. The defect was successfully closed by hemostatic clips. 